\title{
Rapid Method for Estimation of Paraffinicity or Naphthenicity of Middle Distillates Using a Disposable Column
}

\author{
Sadao Matsuzawa*, Osamu Setokuchi, Tadato Yamamoto, Yukio Shimizu, \\ and Mitsuhisa TAMURA \\ National Research Institute for Pollution and Resources, \\ 16-3, Onogawa, Tsukuba, Ibaraki 305
}

(Received September 9, 1988)

\begin{abstract}
A rapid method for estimation of paraffinicity or naphthenicity of middle distillates $\left(200 \sim 400^{\circ} \mathrm{C}\right)$ is described. This method uses a reversed-phase (C18) disposable column and methanol as an eluent to separate the paraffinic components in a $0.2 \mathrm{~m} l$ sample. Estimation can be made by use of the relations involving percentages of the retained components on the disposable column, specific gravities $\left(15 / 4^{\circ} \mathrm{C}\right)$ of the oils, and characterization factors, Ks. This simple and efficient method gives more exact information about paraffinicity than the conventional method using kinematic viscosity.
\end{abstract}

\section{Introduction}

The characterization factor, $\mathrm{K}$, defined by Watson et al.,1) is widely used for classification of oils into paraffinic, intermediate, and naphthenic "bases," whose $\mathrm{K}$ values are as follows: paraffinic base $>12.15$, intermediate base 11:5 12.1, and naphthenic base $<11.45$. Convenient nomographs $^{2)}$ for determination of $\mathrm{K}$ have been proposed because the original method has been found time-consuming, and no rapid method has yet been found.

This study has been carried out in relation to our work, for the hydrocarbon-group type analysis of petroleum distillates by high-performance liquid chromatography (HPLC) in which estimation of the "base" is needed.3),4) The conventional method,2) which uses kinematic viscosity, API gravity of the oil, and its characterization factor, was modified. The modified method uses a reversed-phase (C18) disposable column for separation of the paraffinic components in the oil and can eliminate the drawbacks of inefficient determination of kinematic viscosity.

\section{Experimental}

Chemically bonded C18 silica, which is commonly used as a column packing for the analyses of polar compounds (e.g., polynuclear aromatic hydrocarbons), may also be applicable to separation of nonpolar compounds, depending on elution conditions. However, very few reports concerning this application are available.

\footnotetext{
* To whom correspondence should be addressed.
}

Lundanes et al.5) reported that, for analytical C18 column, the retention of $n$-paraffins increases with increasing carbon number and that large $n$ paraffins elute after elutions of isoparaffins and naphthenes. Further, Tchapla et al.6) and Garrigues? ${ }^{7)}$ showed that large alkyl chains increase retention of aromatic hydrocarbons. Recently, Theobald ${ }^{8)}$ reported the usefulness of disposable C18 column for the separation of product oils. These reports imply the possibility of estimating paraffinicity or naphthenicity of oils by weighing the amounts of retained components on the disposable column, after eluting polar compounds with a polar solvent.

In this work, disposable SEP-PAK C18 (Waters) and methanol (LC-grade, Wako Pure Chemical Industries) were used as a reversed-phase column and as the eluent, respectively. $5 \mathrm{ml}$ of methanol suitable for elution of most of the aromatics (checked by HPLC with silica column) was employed in each separation. The model compounds used were purchased from various sources and used as received. The following distillates: $230 \sim 290^{\circ} \mathrm{C}, \quad 290 \sim 340^{\circ} \mathrm{C}$, and $340 \sim 400^{\circ} \mathrm{C}$ cuts each from Gach Saran (GS), Kuwait (KW), Taching (T) crude oils, a Cold Lake (CL) tar sand bitumen, and three hydrocracked oils (H-GS-V, $\mathrm{H}-\mathrm{T}-\mathrm{V}$ and $\mathrm{H}-\mathrm{CL})$ were used for clarifying the relations between percentages of the retained components and $\mathrm{K}$ values.

After weighing the disposable column (weight: $\left.\mathrm{W}_{0}\right)$, it was placed on the tip of a syringe $(10 \mathrm{ml})$; then about $0.2 \mathrm{ml}$ of a sample was poured into the column with a pipette; a slight pressure was applied on it with the plunger to disperse the 
Table 1 Percentages of Retention for Model Compounds

\begin{tabular}{|c|c|c|c|}
\hline Hydrocarbon type & Compound & (b.p.) & Retention, wt\% \\
\hline \multirow[t]{3}{*}{ Normal-paraffins } & $n$-Dodecane & $(216)$ & 5.0 \\
\hline & $n$-Tetradecane & $(251)$ & 49.2 \\
\hline & $n$-Hexadecane & $(280)$ & 70.9 \\
\hline \multirow[t]{3}{*}{ Isoparaffins } & $2,2,4,4,6,8,8$ & & \\
\hline & Heptamethylnonane & $(240)$ & 14.9 \\
\hline & $\begin{array}{l}2,6,10,14- \\
\text { Tetramethylpentadecane }\end{array}$ & $(296)$ & 73.1 \\
\hline \multirow{4}{*}{$\begin{array}{l}\text { Cycloparaffines } \\
\text { (Naphthenes) }\end{array}$} & Decalin & $(190)$ & 5.9 \\
\hline & $n$-Hexylcyclohexane & $(221)$ & 3.8 \\
\hline & $\begin{array}{l}n \text {-Decylcyclohexane } \\
1,2,3,4,5,6,7,8 \text { - }\end{array}$ & $(-)$ & 74.6 \\
\hline & Octahydrophenanthrene & $(-)$ & 20.5 \\
\hline \multirow[t]{4}{*}{ Olefins } & 1-Dodecene & (213) & 2.6 \\
\hline & 1-Tetradecene & $(251)$ & 11.5 \\
\hline & 1-Hexadecene & $(274)$ & 42.5 \\
\hline & 1-Octadecene & $(320)^{*}$ & 71.4 \\
\hline \multirow[t]{3}{*}{ Aromatics } & Tetralin & $(207)$ & 3.3 \\
\hline & $n$-Octylbenzene & $(264)$ & 3.8 \\
\hline & $n$-Pentadecylbenzene & $(365)^{*}$ & 70.2 \\
\hline
\end{tabular}

* These values were obtained by converting the boiling points under vacuum by using a nomograph.

sample onto the column packing. The column, which contained the sample, was removed from the syringe and weighed $\left(\mathrm{W}_{\mathrm{s}}\right)$ to determine the amount of sample taken. After weighing, the column was again placed on the tip of the syringe for eluting with $5 \mathrm{ml}$ of methanol. The methanol poured into the syringe barrel was gradually pumped with the plunger; then, the column was connected to an aspirator and evacuated for five minutes to remove most of the methanol remained in the column. Further, the column was dried, under 10 to 20 torr, in a vacuum oven at $50^{\circ} \mathrm{C}$ for thirty minutes, and then weighed $\left(W_{P}\right)$ after allowing it to stand in a desicator for five minutes. The amount and percentage of retained components, were determined by using the following equations: $\mathrm{W}_{\mathrm{P}}-0.9973 \mathrm{~W}_{0}$ and $\left(\mathrm{W}_{\mathrm{P}}-0.9973 \mathrm{~W}_{0} / \mathrm{W}_{\mathrm{S}}-\right.$ $\left.\mathrm{W}_{0}\right) \times 100$, respectively.

\section{Results and Discussion}

\subsection{Blank Tests for the Disposable Column}

Junk et al.9) tested procedural blanks from disposable C18 columns and pointed out that very little material was obtained by elution with methanol. Moreover, Theobald's report ${ }^{8}$ showed that the amount of background compounds for the disposable $\mathrm{Cl} 8$ column was small.

Figure 1 shows the changes in weight of the SEP-PAK Cl8 by heating, with and without methanol treatment. The solid line shows that the weight loss by thirty-minute heating, without methanol treatment, is about $0.22 \%$. In addition, the dotted line shows that methanol treatment increases the weight loss by $0.05 \%$ as compared with that by heating. Based on these results, minus $0.27 \%$ correction was made on the column weight after such treatments. Correction was

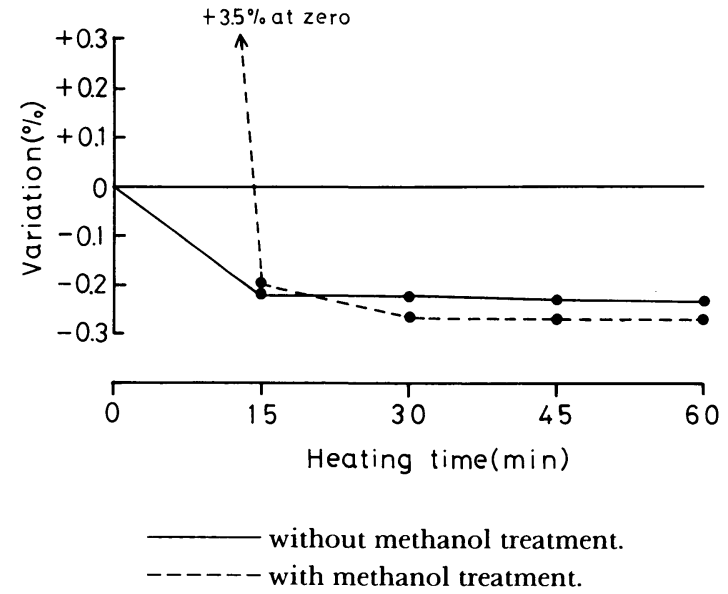

Fig. 1 Changes in Weight of the Disposable Column by Treatment

introduced in the equations for determining the amount and percentage of the retained components. The increase in weight of the column, with methanol treatment, at zero minute is due to the methanol remained after evacuation with the aspirator.

\subsection{Elution Characteristics of Model Compounds}

Table 1 shows the percentages of retention on SEP-PAK C18, after elution with $5 \mathrm{ml}$ of methanol, for $n$ - and isoparaffins, naphthenes, olefins, and some aromatics. It is obvious, from the Table, that $5 \mathrm{ml}$ of methanol elutes not only aromatics but also $n$-paraffins, isoparaffins, naphthenes and olefins of low boiling points, and condensed naphthenes. However, high-boiling $\left(>250^{\circ} \mathrm{C}\right) n$ paraffins and other types of hydrocarbons with a long alkyl chain are retained. These results mean that the compounds possessing paraffinic character are generally retained under such elution 
conditions. Low-boiling $n$-paraffins may be eluted together with aromatics under severer conditions to remove most of the aromatics. ${ }^{8)}$

Table 2 Percentages of Retained Components for Middle Distillates

\begin{tabular}{rcccc}
\hline No. & Distillate & $\left({ }^{\circ} \mathrm{C}\right)$ & $\mathrm{K}$ & $\begin{array}{c}\text { Retained } \\
\text { Compo., wt\% }\end{array}$ \\
\hline l & Gach Saran & $230 \sim 290$ & 11.6 & 26.6 \\
2 & (GS) & $290 \sim 340$ & 11.7 & 54.0 \\
3 & & $340 \sim 400$ & 11.6 & 71.4 \\
4 & Kuwaite & $230 \sim 290$ & 11.7 & 24.4 \\
5 & (KW) & $290 \sim 340$ & 11.7 & 55.2 \\
6 & & $340 \sim 400$ & 11.6 & 71.3 \\
7 & Taching & $230 \sim 290$ & 12.0 & 31.5 \\
8 & (T) & $290 \sim 340$ & 12.3 & 72.1 \\
9 & & $340 \sim 400$ & 12.3 & 86.4 \\
10 & Cold Lake & $230 \sim 290$ & 10.9 & 14.3 \\
11 & (GL) & $290 \sim 340$ & 11.1 & 42.9 \\
12 & & $340 \sim 400$ & 11.0 & 64.9 \\
13 & H-GS-V & $230 \sim 290$ & 11.2 & 18.4 \\
14 & & $290 \sim 340$ & 11.5 & 49.9 \\
15 & & $340 \sim 400$ & 11.3 & 65.2 \\
16 & H-T-V & $230 \sim 290$ & 11.8 & 28.5 \\
17 & & $290 \sim 340$ & 11.9 & 62.9 \\
18 & & $340 \sim 400$ & 12.0 & 78.9 \\
19 & H-CL & $230 \sim 290$ & 11.2 & 14.8 \\
20 & & $290 \sim 340$ & 11.3 & 46.8 \\
21 & & $340 \sim 400$ & 11.1 & 62.6 \\
\hline
\end{tabular}

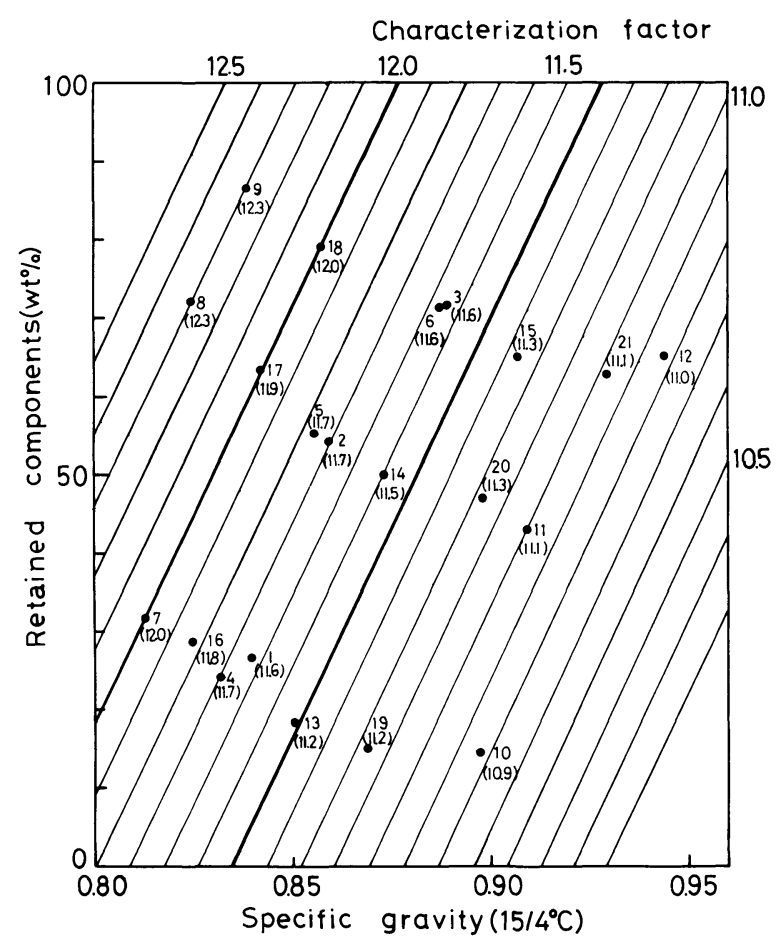

Numbers 1 to 21 correspond to those in Table 2. Measured Ks are shown in parentheses.

Fig. 2 Relations Involving Percentage of Retained Components, Specific Gravity of Oil and Characterization Factor(K)

\subsection{Relation between Percentage of Retained Components and $K$}

Table 2 shows percentages of retained (paraffinic) components, after elution with $5 \mathrm{ml}$ of methanol, for middle distillates from crude oils, a tar sand bitumen, and hydrocracked oils, and $\mathrm{K}$. In general, percentages of the retained components of paraffinic base oils $(K>12.15)$ are relatively large and those for naphthenic base oils $(\mathrm{K}<11.45)$ in the same boiling range are small. Moreover, it is clear that, by comparison with percentages for other samples in the same boiling range, Taching $230 \sim 290^{\circ} \mathrm{C}, \mathrm{H}-\mathrm{T}-\mathrm{V} 290 \sim 340^{\circ} \mathrm{C}$ and $\mathrm{H}-\mathrm{T}-\mathrm{V} \quad 340 \sim 400^{\circ} \mathrm{C}$, are rich in paraffinic components, although these oils are classified as intermediate base by K. Actually, in our HPLC work, accurate values were obtained when these samples were classified as paraffinic base oils. Thus, the percentages obtained by using a disposable column are more effective than $\mathrm{K}$ for the estimation of paraffinicity of oils.

In practical use of this technique for estimation of "bases" of oils, the effect of boiling point on the percentage of retained components must be considered. This problem is solved by use of specific gravities $\left(15 / 4^{\circ} \mathrm{C}\right)$ of the oils. Figure 2 shows a family of relations involving percentages of retained (paraffinic) components, specific gravities of the oils and Ks. Each line, whose slope is based on that of the standard line for $\mathrm{K}=12.0$ indicates the $\mathrm{K}$ value. The distance between two lines is determined by subdividing the distance from $\mathrm{K}=11.5$ to $\mathrm{K}=12.0$ by 5 . It is obvious, from this Figure, that measured $\mathrm{K}$ values in parentheses coincided well with the $\mathrm{K}$ values indicated by the lines, except those for some naphthenic oils. Namely, this Figure is useful as a nomograph for the classification of oils into individual bases. In this case, the use of $\mathrm{K}$ values from $>12.0$ and $<11.4$ is recommended for paraffinic and naphthenic base oils, respectively.

This method, which uses a disposable column, is very simple and efficient (only ten minutes are required for chromatography of a sample). Estimation of the "base" for twenty samples a day is possible by this method, even if duplicate testings are required, while, at best, only ten samples can be tested by the conventional method using kinematic viscosity. In addition, this method may be applicable to the prediction of pour points for gas oils. Samples of low pour points generally show lower percentages of retained (paraffinic) components.

\section{References}

1) Nelson, W. L., "Petroleum Refinery Engineering” 4th 
Ed., 81 (1958), McGraw-hill Kogakusha.

2) Nelson, W. L., "Petroleum Refinery Engineering" 4th Ed., 179 (1958), McGraw-hill Kogakusha.

3) Matsuzawa, S., Nakamura, E., Sekiyu Gakkaishi, 27, (3), 263 (1984).

4) Matsuzawa, S., Nakamura, E., Sekiyu Gakkaishi, 27, (6), 500 (1984).

5) Lundanes, E., GreiBrokk, T., J. Chromatogr., 322, 347
(1985).

6) Tchapla, A., Colin, H., Guiochon, G., Anal. Chem., 56, 621 (1984).

7) Garrigues, P., Parlanti, E., Radke, M., Bellocq, J., Willsch, H., Ewald, M., J. Chromatogr., 395, 217 (1987).

8) Theobald, N., Analytica Chimica Acta, 204, 135 (1988).

9) Junk, G. A., Avery, M. J., Richard, J. J., Anal. Chem., 60, 1347 (1988).

要旨

使い捨てカラムを利用する中間留分のパラフィン性またはナフテン性の簡便な判定法

松沢 貞夫, 瀬戸口 修, 山本 忠人, 清水 征生, 田村 光久

公害資源研究所, 305 茨城県つくば市小野川 16-3

高速液体クロマトグラフィー（HPLC）による中間留分の炭 化水素タイプ分析において, 試料のパラフィン性やナフテン性 を考慮して示差屈折率検出器の検出感度補正を行うと, より正 確な飽和分の定量值が得られる ${ }^{3), 4)}$ 。本研究では，これらパラ フィン性やナフテン性の判定に使い捨て可能なカラム （Waters, SEP-PAKC18）を用い，動粘度測定を必要とする従 来法”) の時間短縮をはかった。すなわち判定は, 試料 $(0.2$ $\mathrm{m} l$ ) をメタノール溶出した際カラムに保持された(パラフィ ン性）成分の割合, 試料の比重 $\left(15 / 4^{\circ} \mathrm{C}\right)$ および特性係数 $\mathrm{K}^{1)}$ の関係を用いて行う。

溶出に用いるメタノール量は，芳香族成分がほとんど溶出さ れる量 $5 \mathrm{ml}$ とした。また被保持成分の定量および割合の算出 に際し，加熱およびメタノール処理にともなうカラム重量の減 少分 $0.27 \%$ （Fig. 1) の補正を行った。この使い捨てカラム により保持される成分は, 高沸点 $\left(250^{\circ} \mathrm{C}\right.$ 以上) $n$-パラフィン
の他，長いアルキル基を有するイソパラフィン，ナフテン，オ レフィン，芳香族などであった（Table 1)。中間留分に応用し た結果，得られた被保持（パラフィン性）成分の割合は，同一 沸点範囲で比較した場合，パラフィン基が大きくナフテン基が 小さかった（Table 2)。またこの被保持成分の割合によると， 従来法では中間基と判定される試料のパラフィン性が明らかに なった。パラフィン性またはナフテン性の判定は，被保持成分 の割合，試料の比重 $\left(15 / 4^{\circ} \mathrm{C}\right)$ および特性係数 $\mathrm{K}$ の関係 (Fig. 2) で行うことができる。なお本法では，K>12.0をパラ フィン基， $\mathrm{K}<11.4$ をナフテン基油とする。

この使い捨てカラムによる分離法は，パラフィン性またはナ フテン性の判定の他, 軽油の流動点の推定にも利用できると考 えられる。すなわち, 流動点の低い軽油ほど, 得られる被保持 成分の割合が小さかった。

\section{Keywords}

LC, Middle distillate, Characterization, Paraffin, Gas oil, Naphthene 